\title{
$ノ-卜$
}

Notes

$\left(\begin{array}{l}\text { Jpn. J. Hosp. Pharm. } \\ \text { 24(6) } 683-686(1998)\end{array}\right)$

\section{ジゴキシンの有効治療域内で視覚異常が出現した 1 症例}

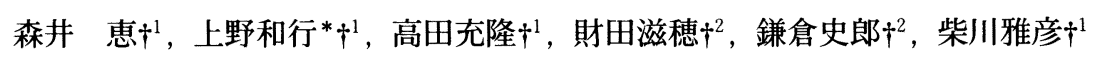

国立循環器病センター薬剤部 $\dagger^{1}$, 同内科 $\dagger^{2}$

\section{Reports of Patients Consultation, Part 1 \\ A Case Report of Digoxin Toxicity Presented with Visual Disturbance}

\author{
MEGUMI MORII $\dagger^{1}$, KAZUYUKI UENO $* \dagger^{1}$, MITSUTAKA TAKADA $\dagger^{1}$, SHIGEHO TAKARADA $\dagger^{2}$, \\ SHIRO KAMAKURA $\dagger^{2}$ and MASAHIKO SHIBAKAWA $\dagger^{1}$
}

Department of Pharmacy $\dagger^{-1}$ and Internal Medicine $\dagger^{2}$, National Cardiovascular Center

\author{
$\left(\begin{array}{lc}\text { Received January 5, } & 1998 \\ \text { Accepted June 16, } & 1998\end{array}\right)$
}

\begin{abstract}
A 65-year-old woman inpatient had been administered methyldigoxin, verapamil and warfarin for the treatment of artrial fibrillation and mitral stenosis disease. About six day after the start of treatment the dose of methyldigoxin was increased from 0.1 to $0.2 \mathrm{mg} / \mathrm{day}$ and, as a result, a visual disturbance occurred. However, no other side effects of digoxin were not presented and the serum digoxin concentration was found to be within the normal therapeutic range. The dose was decreased and about five days later, her side effects disappeared. This case suggested that such side effects of digoxin as visual disturbance therefore need to be carfully monitored when ever digoxin and verapamil, which is one of the inhibitors of P-glycoprotein, are coadministered.
\end{abstract}

Key words — digoxin, veparamil, interaction, side effect, visual disturbance

緒言

薬剤師による服薬指導が各施設で実施されるよ うになってきた．特に医療法改正に伴い薬剤師の 医療における責任が問われるようになり，服薬指 導の実態が問題とされるようになってきた，当院 は一環した循環器病の予防・診断・治療法の開 発, 成因・病態の解明などを押し進めている循環 器病専門の施設である。薬剤部ではすでに全病棟 に薬剤師が進出し, 大部分の患者の服薬指導を実

$\dagger^{1,2}$ 大阪府吹田市藤白台 5-7-1；5-7-1， Fujishirodai, Suita, Osaka, 565-8565 Japan
施している，そこで，薬荗師による服薬指導を通 じて，ジゴキシン投薬患者に打いて有効治療域内 であるにもかかわらず副作用が発現し，投薬量の 減少により消失した一例を報告する。

\section{症例}

症例は年齢65歳, 体重 $71 \mathrm{~kg}$, 女性. 僧帽弁狭 窄, 心房細動にてメチルジゴキシン $0.1 \mathrm{mg} /$ 日, ベラパミル $120 \mathrm{mg} /$ 日, ワルファリン $2.5 \mathrm{mg} /$ 日投 薬中の入院中の患者であった. 入院 10 日後のメチ ルジゴキシンの血清中濃度はジゴキシンとして $0.7 \mathrm{ng} / \mathrm{ml}$ であった。この時点で薬剤師による服 
薬指導を行ったが投薬 3 郕による副作用は認めら れなかった．入院20日後メチルジゴキシンの投楽 量を $0.2 \mathrm{mg}$ /日に増量した. 血清中濃度は増量後 6 日目で $1.4 \mathrm{ng} / \mathrm{ml}$ で有効域内であった。かつ副 作用の訴え, あるいは副作用の症状は出現してい なかった. その 5 日後, 服薬指導時患者に再度ジ ゴキシンの一般的な副作用および視覚異常を説明 したところ, 近頃目がまぶしく, キラキラ感じる との訴えであった. 本症状は 4 5 日前から少し ずつ出現していたとのことであった。しかし食欲 不振などの消化器系, および循環器系への副作用 は認められなかった。 そこで, ジゴキシンによる 副作用としての視覚異常と判断し, 主治医と相談 の結果，メチルジゴキシンの投薬量を 0.2 および $0.1 \mathrm{mg} /$ 日交互投薬に減量した. 減量後約 5 日経 過時点で副作用の消失を確認した。消失 5 日後に 血清中濃度を測定した結果 $1.4 \mathrm{ng} / \mathrm{ml}(0.2 \mathrm{mg} /$ 日 投薬後) で, 以後副作用の出現は認められなかっ た。症例の投薬歴等を図 1 に示した。 また，本症 例の検査データおよびバイタルデータは調査期間 中変動はなかった（主な検查データ；BUN15-21 $\mathrm{mg} / \mathrm{dl}, \mathrm{Scr} 0.7-0.8 \mathrm{mg} / \mathrm{dl}$, GOT15-19u, GPT11-16 u).

本症例の体内動態パラメータをジゴキシンの母
集団解析データ1)を用いてべイジァン法にて，2 回の測定値より予測した結果は消失半減期 64.6 時 間，分布容積 $466 \mathrm{~L}$ ，また $0.2 \mathrm{mg} /$ 日に増量後 11 日 目の予測值は $1.41 \mathrm{ng} / \mathrm{ml}$ であった。

血清中メチルジゴキシン濃度は FPIA 法（TDX アナライザー, ダイナボット社, 東京) にてジゴ キシンとして測定した。

\section{考察}

ジゴキシンの有効血中濃度域は一般に $0.8-2.0$ $\mathrm{ng} / \mathrm{ml}$ と報告2-6)されている。またすでにジゴキシ ンによる視覚異常は報告7-8)されているが，血中 濃度が有効域を越えた場合の報告である。筆者ら は日本人を対象としてジゴキシンの副作用域を再 検討した結果 $1.5 \mathrm{ng} / \mathrm{ml}$ を越えると約 $60 \%$ に副作 用が出現することを報告した ${ }^{10)}$. また，その内容 は消化器系が主で約 $80 \%$ あったた. かつ循環器系 への副作用は血清中濃度の上昇とともにその比率 が高くなることも報告した ${ }^{11)}$. 本症例の血清中濃 度は増量 6 日目で $1.4 \mathrm{ng} / \mathrm{ml}$ であった。本症例の 体内動態パラメータの解析より消失半減期は 64.6 時間と予測され，クリアランスを考えれば比較的 小さい患者であった. 増量 6 日時点では血清中濃 度は定常状態に達していないと考えられるが, 定

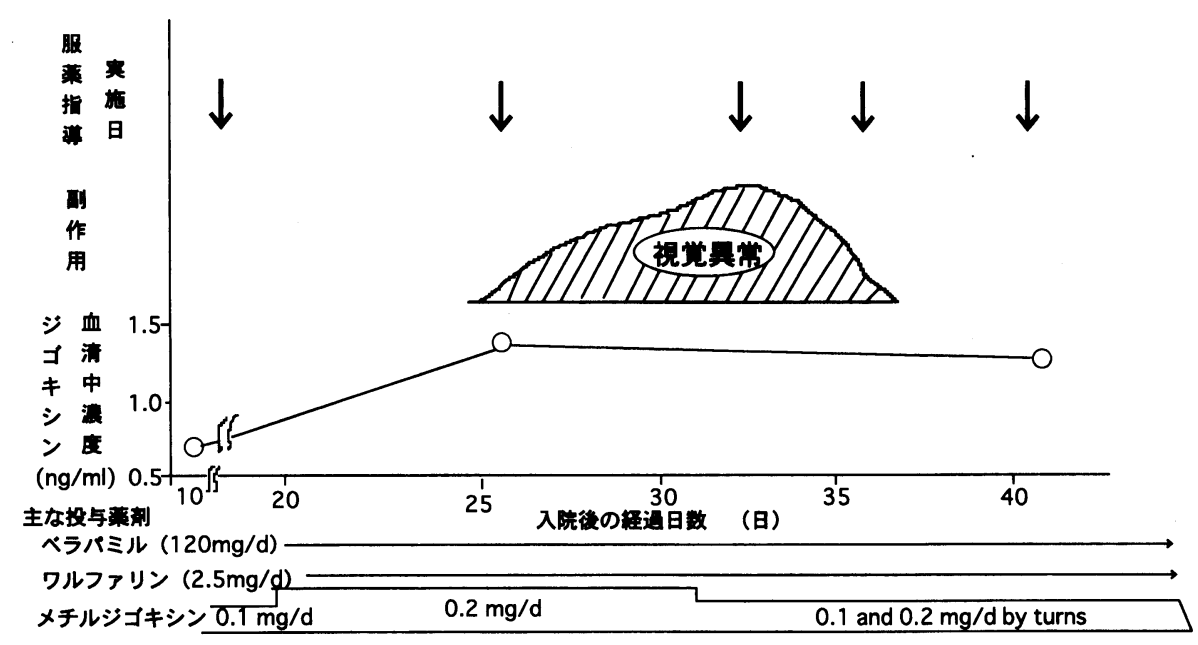

図 1 . 服薬指導によりジゴキシンの副作用を消失し得た 1 症例 
常状態後の予測值をも考慮すれば, 視覚異常の副 作用が出現した時点においては血清中ジゴキシン 濃度は增量 5 日後の值 $(1.4 \mu \mathrm{g} / \mathrm{ml})$ を越えてい る可能性は高いと考えられるが，中毒域とされて いる. $2.0 \mu \mathrm{g} / \mathrm{ml}$ を越えている可能性は低いとえ られる。しがたって，本症例のジゴキシンによる 副作用としての視覚異常は従来有効域とされてい る0.8-2.0 $\mu \mathrm{g} / \mathrm{ml}$ 内であるにもかかわらず出現 したことになる，一方，メチルジゴキシンは体内 でジゴキシンに代謝される。したがって，生体内 ではメチルジゴキシンとジゴキシンが存在し, FPIA 法ではその両方の薬物を測定することにな る、しかし FPIA 法では両薬物の交差性がほとん ど変わらないため, 今回の症例においては測定に おける差は問題とはならないと考えられる.

近年, ジゴキシンの腎からの排泄の機序が解明 され，尿細管への排泄は $\mathrm{P}$ 糖蛋白質により輸送 されることが明らかになっだ2)。また，これまで シゴキシンとの併用によりジゴキシンのクリアラ ンスを減少させる薬物が多く報告されており，本 相互作用の機序は併用薬が $\mathrm{P}$ 糖蛋白質によるジ ゴキシンの輸送を阻害するためであると報告され ている。例えば, ベラパミル13), キニジン ${ }^{14,15)}$, イトラコナゾール ${ }^{16.17)}$ な゙の薬物が本機序により ジゴキシンのクリアランスを減少させる。一方,

$\mathrm{P}$ 糖蛋白質 ${ }^{18)}$ は腎の尿細管だけでなく, 副腎, 子 宮, 肝藏, 大腸, 小腸にも存在することが知られ ている。 また, 血液・脳関門では脳内への脂溶性 物質の移行に対する排泄ポンプとして働くといわ れている ${ }^{19)}$. 本症例においては $\mathrm{P}$ 糖蛋白質阻害剤 であるべラパミルが併用されている。したがっ て, 本症例のクリアランスが小さいのは, ベラパ ミル併用によるジゴキシンのクリアランスの減少 が示唆される。一方, 血液・脳関門における $\mathrm{P}$ 糖蛋白質によりジゴキシンをはじめ種々の薬物が 輸送されると報告されている20-22). ヒトにおける in vivo の報告はないが，本症例においては，P糖 蛋白質阻害剤であるべラパミル併用により, 血 液・脳関門における P 糖蛋白質を阻害すること
で, 血液中の濃度から予想される以上に脳内ジゴ キシン濃度が上昇している可能性が示唆される. 本症例は視覚異常の他の副作用は認められなかっ た。かつ，血清中濃度が有効域内にあったにもか かわらず視覚異常という脳を介したジゴキシンの 副作用が出現したのは, ベラパミルの併用により 脳内ジゴキシン濃度の異常の上昇による可能性が 示唆される。したがって，本症例より $\mathrm{P}$ 糖蛋白 質阻害薬とジゴキシンの併用時においてはクリア ランスの減少だけでなく, 有効域内においても脳 を介する副作用出現の可能性が示唆される. 今後 併用時の副作用の出現により注意を払う必要性が あるとともに, 基礎的研究を含めた詳細なメカ二 ズムの検討が必要である.

結論

薬剤師による服薬指導を通じて, ジゴキシンの 有効治療域内で視覚異常が出現した 1 症例を経験 した結果以下の結論が示唆された。

1. ジゴキシン投薬時べラパミルのような $\mathrm{P}$ 糖蛋白質阻害薬併用時にはジゴキシンが有効治療 濃度域内であっても副作用の発現に注意しなけれ ばならない.

2.ジゴキシンと $\mathrm{P}$ 糖蛋白質阻害薬を併用時 においては中毒域の再検討が望まれる.

\section{引用文献}

1) 堀了平, 宮崎勝巳, 水柿道直, 緒方宏泰, 後藤 光良, 他 TDM 研究, 11, 7-17 (1994).

2) Smith TW, and Haber E., J. Clin. Invest., 49, 2377-2386 (1970).

3) Everet DC and Chapman., Br. Heart J., 33, 540-545 (1971).

4) Beller GA Smith TW, Abelmann WH, Haber E, and Hood WB., New. EngI. J. Med., 284, 989-997 (1971).

5) Huffman DH, Crow JW, Pentikainen $P$, and Azarnoff., Am. Heart J., 91, 28-34 (1976).

6) Lee TH, and Smith TW., Clin. Pharmacokinet., 8, 279-285 (1983).

7) Jonson LN., Newrology, 40, 1469-1470 (1990).

8) Eisendrath SJ, Gershengorn $\mathrm{KN}$, and Unger 
R., Am. Heart J., 106, 419-420 (1983).

9) Kerr DJ, Elliot HL, Hlllis WS., Br. Med. J., 284, 162-163 (1982).

10)上野和行, 宮井一義 病院薬学, 17, 34-37 (1991).

11）上野和行, 内海順子, 石田保晴, 川口義廣, 山 口理世, 加藤元一, 有本潤司, 鈴木淑男, 小山 道子, 尾藤慶三, 小西興承, 病院薬学, 21, 106-108 (1995).

12) Tanigawara $Y$, Okamura $N$, Hirai $M$, Yasuhara M, Ueda K, Kioka N, Komano $\mathrm{T}$ and Hori R., J. Pharmacol. Exp. Ther., 263, 840845 (1992).

13) Pederson KE, Dorph-Pederson A, Hvidt S, Klitgaard NA, and NielsenKudsk F., Clin. Pharmacol. Ther., 30, 311-316 (1981).

14) Hager WD, Fenster P, Mayersohn M, Perrier D, Gravers P, Marcus FI and Goldman S., $N$. Engl. J. Med., 300, 1238-1241 (1979).
15) Ochs H, Greenblatt DJ, and Bodem G., Clin. Pharmacol. Ther., 28, 340-345 (1980).

16) Ito $\mathrm{S}$ and Koren G, Ann. Pharmacother., 31, 1091-1092 (1997).

17) Partanen J, Jalava KM and Neuvonen PJ, Pharmacol. Toxicol., 79, 274-276 (1996).

18) Leveqoe D and Jehl F., Anticancer Res., 15, 331-336 (1995).

19) 辻彰, Molecular Medicine, 30, 748-755 (1993).

20) Schinkel AH, Smit JJM, Tellingen O, Beijnen JH, Wagenaar E, Deemter L, Mol AAAM, Valk MA, Robanus-Maandag EC, Riele HPl, Berns AJM, Borst P., Cell, 77, 491-502 (1994).

21) Schinkel AH, Wagenaar E, Deemter L, Mol CAAM, Borst P., J. Clin. Invest., 96, 16981705 (1995).

22) Schinkel AH, Wagenaar E, Caria AAM, Deemter L., J. Clin. Invest., 97, 2517-2524 (1996). 